\title{
Effect of dates of sowing, varieties and growth regulator on growth and yield attributes on summer groundnut (Arachis hypogaea L.) under north Gujarat agro-climatic conditions
}

\author{
B.D. JANGILWAD*, R.D. PAGAR, K.V. WARKAD AND S.K. PATEL \\ Department of Agronomy, C.P. College of Agriculture, Sardarkrushinagar Dantiwada Agricultural University, \\ Sardarkrushinagar, BANASKANTHA(GUJARAT) INDIA
}

\begin{abstract}
A field experiment was conducted during summer-2010 at Agronomy Instructional Farm, C.P. College of Agriculture, Sardarkrushinagar Dantiwada Agricultural University, Sardarkrushinagar, to study the effect of dates of sowing, varieties and growth regulator on growth and yield attributes on summer groundnut (Arachis hypogeia L.) under north Gujarat agro-climatic conditions. The soil of the experimental field was loamy sand in texture, low in nitrogen, medium in available phosphorus and rich in available potash. The experiment was laid out in Factorial Randomized Block Design with three replications. Eighteen treatment combinations comprised of three levels of dates of sowing viz., $\mathrm{D}_{1}-1^{\text {st }}$ February, $\mathrm{D}_{2}-14^{\text {th }}$ February and $\mathrm{D}_{3}-28^{\text {th }}$ February; three levels of varieties viz., $\mathrm{V}_{1}-\mathrm{GG}-2, \mathrm{~V}_{2}-\mathrm{GG}-5$ and $\mathrm{V}_{3}$ - GG-7 and two levels of growth regulator viz., $\mathrm{G}_{0}-$ control and $\mathrm{G}_{1}-50 \mathrm{ppm} \mathrm{IBA}$ spray 20 and 40 DAS. The performance of all growth and yield attributes recorded highest plant height $(27.35 \mathrm{~cm})$, pods yield $(3065$ $\mathrm{kg} / \mathrm{ha}$ )and test weight (50.42 $\mathrm{g}$ ) was observed in 28 February snowcrop.
\end{abstract}

Key Words : Dates of sowing, Varieties, Growth regulator, Growth, Yield attributes

View Point Article : Jangilwad, B.D., Pagar, R.D., Warkad, K.V. and Patel, S.K. (2015). Effect of dates of sowing, varieties and growth regulator on growth and yield attributes on summer groundnut (Arachis hypogaea L.) under north Gujarat agro-climatic conditions. Internat. J. agric. Sci., 11 (2) : 257-263.

Article History : Received : 28.03.2015; Revised : 13.05.2015; Accepted : 22.05.2015

\footnotetext{
* Author for correspondence
} 